\author{
Mikolaj Bartlomiejczyk \\ Gdask University of Technology, Faculty of Electrical and Control Engineering \\ G. Narutowicza 11/12,80-233 Gdask, Poland, mikolaj.bartlomiejczyk@pg.edu.pl
}

\title{
DYMANIC CHATGING OF ELECTRIC BUSES - THE ELEMENT EMOBILITY IN PUBLIC TRANSPORTATION
}

\begin{abstract}
Night charging and fast charging are currently the two most common systems for charging electric buses. Despite the fact that numerous trial installations were started, neither of these two systems has obtained unqualified approval of the users. The alternative is to charge vehicles in motion - dynamic charging which combines the advantages of trolleybus transport and of electric buses. One of the advantages is the reduction of risks associated with the electrification of urban transport. The investment in the construction of the traction network allows you to reduce the costs associated with the purchase and replacement of traction batteries, as well as increase the flexibility of the transport system. The article presents the financial benefits resulting from the use of a dynamic charging system.
\end{abstract}

Keywords: Electric bus, trolleybus, traction batteries, Eliptic, emobility

Introduction. Despite the continuous development of electrochemical batteries technology and the multitude of electric buses on offer, it is still not possible to exploit electric buses in urban transport on allday basis without the necessity of charging them. Therefore it is necessary to build point-to-point contact charging stations or induction charging stations at the terminals. This results in substantial financial outlays connected with the construction of charging stations, and in the necessity to extend the stopping time at the terminals; there are also problems which arise in the situation where the route is changes. The alternative solution is the so-called Dynamic Charging, also called In Motion Charging (IMC). It consists in building an infrastructure allowing for charging vehicles in motion, most often with the use of overhead contact line (Fig. 1) [5-7]. What is more, in the cities where tram network is already exploited, there is a possibility to use the elements of the tram infrastructure when constructing the catenary for the Dynamic Charging system.

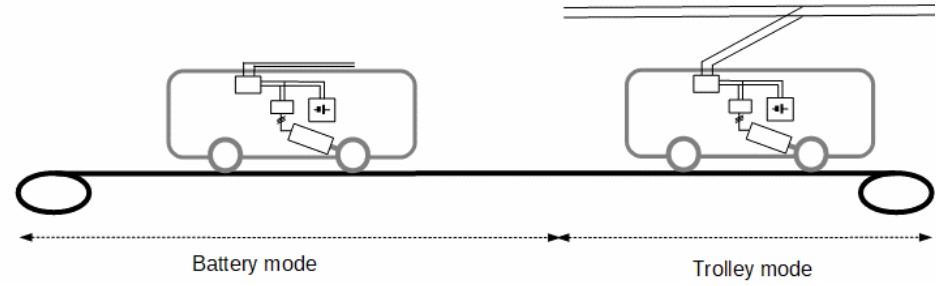

Fig. 1. Idea of dynamic charging system (In motion charging)

The construction of a traction network is associated with significant financial outlays and is the most expensive element of dynamic charging system. For this reason, it is advisable to limit its length. The length of sections accompanied by contact line must be sufficient to charge the traction batteries with energy at least equal to the energy necessary to cover the catenary-free section. With currently used vehicles, the minimum degree of coverage with the traction network is at a level of $40 \%-50 \%$ [13]. This value can be reduced by increasing charging power to $25 \%$. In the case of a supply system of $750 \mathrm{~V} \mathrm{DC}$ it is possible to decrease this rate to $20 \%$ [1-3]. In the case of a reduction in the heating power of the vehicle or use thermal pumps, it is possible to reduce the degree of coverage below 20\%. Fig. 2 shows an estimation of the minimal coverage rate in function of charging power, based on, the energy consumption for a standard vehicle was assumed to be $3 \mathrm{kWh} / \mathrm{km}$ (winter) and, correspondingly, for an articulated vehicle $3,9 \mathrm{kWh} / \mathrm{km}$ [15]. 


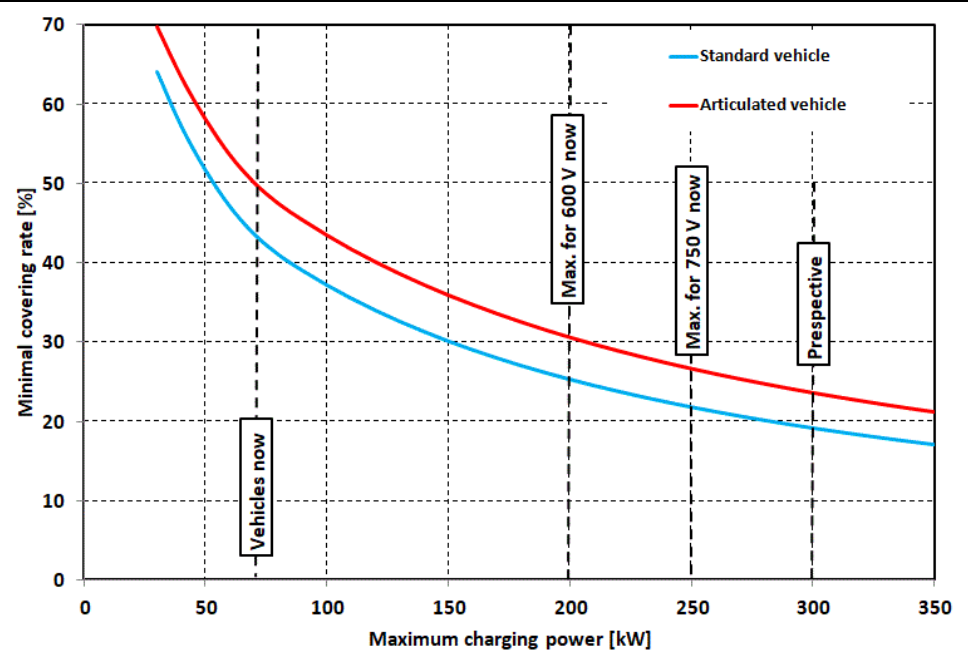

Fig. 2. Minimum catenary coverage in function of maximal charging power [1]

The benefits of dynamic charging. The benefits of using dynamic electric bus charging will be illustrated by an example of line with a length $10 \mathrm{~km}$, which is operated by standard length electrical buses. Maximal energy consumption at the level $3 \mathrm{kWh} / \mathrm{km}$ is assumed.

There are analyzed 3 alternative systems of line electrification (Fig. 3), [15]: is $400 \mathrm{~kW}$,

- operation by standard electrical bus with one charging station and Terminus 1 . The charging power

- operation by dynamic charged battery bus with one $3 \mathrm{~km}$ wired section (variant 1 ),

- operation by dynamic charged battery bus with two wired sections: $1 \mathrm{~km}$ and $2 \mathrm{~km}$ (variant 2).

The average charging power of dynamic charging system is $140 \mathrm{~kW}$, the average velocity in wired section is $20 \mathrm{~km} / \mathrm{h}$. The minimal charge level is assumpted at $50 \%$. In case of standard battery bus the maximal discharge level is $60 \mathrm{kWh}$. With a minimal discharging rate $50 \%$, this requires a $120 \mathrm{kWh}$ traction battery. In fist variant of dynamic charged bus the battery is discharged with energy $42 \mathrm{~kW}$, what allows the required battery capacitance to $84 \mathrm{kWh}$. In the second variant battery is maximally discharged with power 15 $\mathrm{kWh}$. As a result of that, the traction battery with capacitance $30 \mathrm{kWh}$ will be enough to fulfill transportation route conditions.
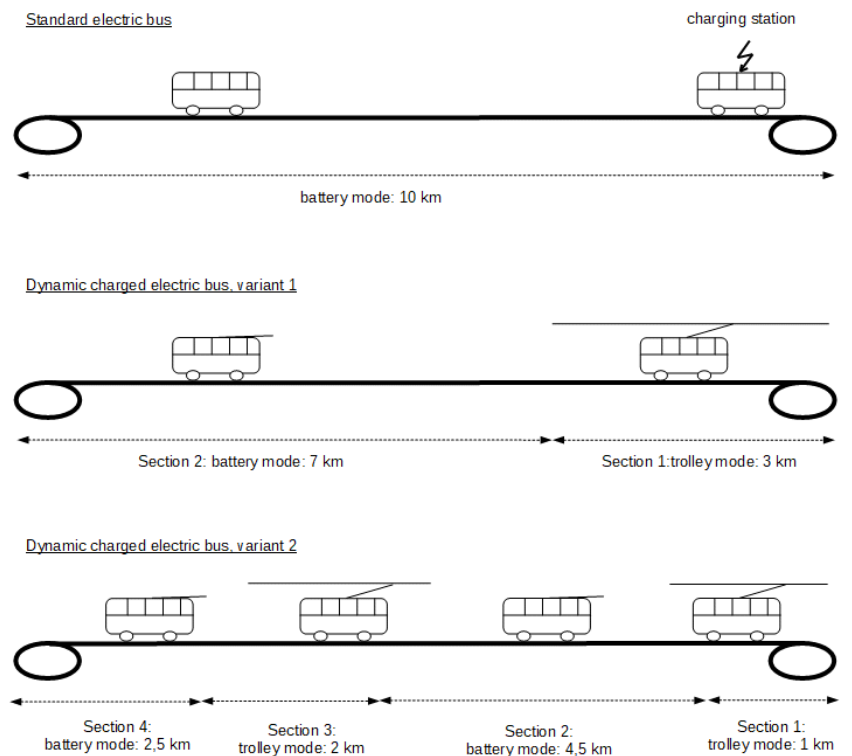

Fig. 3. The scheme of an example of route operated by standard electrical bus and two variants of dynamic charged buses [15]

Covering part of transportation route allows to reduce the required traction battery. The capacitance reduction is bigger in case of using more than one wired sections. This allows to alternate work in mode charging - discharging - charging - discharging. Thanks to this, the depth of discharge is significantly reduced. Considering that the price of the battery is 1000 to 1500 euro for $1 \mathrm{kWh}$ of capacity, the use of overhead contact line saves 90000 euro on one vehicle. In addition, the dynamic charging system does not 
require stops for charging the vehicle, therefore the number of vehicles necessary to operate the line is smaller than in the classic electric bus [15].

Stationary charging involves the necessity to stop the vehicle while it is being charged so for charging time vehicle is unavailable for user. Time is money - so we are losing money while vehicle is charged. What is more, it may result in the need to increase the number of vehicles necessary to operate the line. The table presents the exemplary charging times when we operate route $15 \mathrm{~km}$ and charging stations are localized at both terminuses.

Table 1. The comparison of charging time of electric bus with opportunity charging system

\begin{tabular}{ll}
\hline $\begin{array}{l}\text { Type of } \\
\text { vehicle }\end{array}$ & $\begin{array}{l}\text { Charging } \\
\text { time* }\end{array}$ \\
\hline $12 \mathrm{~m}$ vehicle & $9 \mathrm{~min}$. \\
$15 \mathrm{~m}$ vehicle & $10 \mathrm{~min}$. \\
$18 \mathrm{~m}$ vehicle & $12 \mathrm{~min}$. \\
$24 \mathrm{~m}$ vehicle & $16 \mathrm{~min}$. \\
\hline Assumed energy consumption Energy consumption: $2,2-2,6-3,2-4 \mathrm{kWh} / \mathrm{km}$
\end{tabular}

The elements of risk in transportation systems with electric buses. Electric buses are a relatively new means of transport, so there is not enough experience in operation. The electric vehicle market is developing very dynamically and it is very difficult to determine trends in changes in the purchase price of electric vehicles in the future. In addition, there is no experience related to the operation of traction batteries with a large capacity. The key factor here is the battery life, which is currently difficult to assess. As a result, there is a high risk associated with the entry into service of this kind of transport. The following main elements of risk can be distinguished:

- the risk related to the purchase price of new vehicles,

- the risk related to the cost of replacing the battery,

- risk related to traffic congestion and its influence on charging process.

Currently, the cost of the battery can be up to $50 \%$ of the vehicle price. Moreover, during the entire lifetime of the vehicle it will be necessary to replace the battery at least once. A decline in battery price can be expected, but the size of the reduction is very difficult to assess. What is important, the increase in the development of electromobility and the increase in demand for energy storage can negatively affect the battery prices.

Stationary charging requires an increase in the number of vehicles servicing the transportation line due to the need to provide an adequate time reserve for vehicle charging. This results in an increase in the number of vehicles in service and the number of drivers. This additional cost is difficult to estimate due to the differing ways of organizing driver service in various transport systems, but currently the cost of drivers accounts for up to $50 \%$ of all maintenance costs of the transport system. Thus even a slight increase in the number of rolling stock can cause a significant increase in costs.

The necessity of stopping the vehicle during the time of charging is of primary importance in the context of traffic disturbances caused by traffic congestion. They cause a delay in the arrival time to the final stop (Fig. 4), which shortens the time left to recharge the vehicle. In the case of stationary charging, this may cause situations where the remaining stop time is too short to charge the vehicle and it becomes necessary to use on the reserve vehicle. An exemplary situation is shown of Fig. 5.

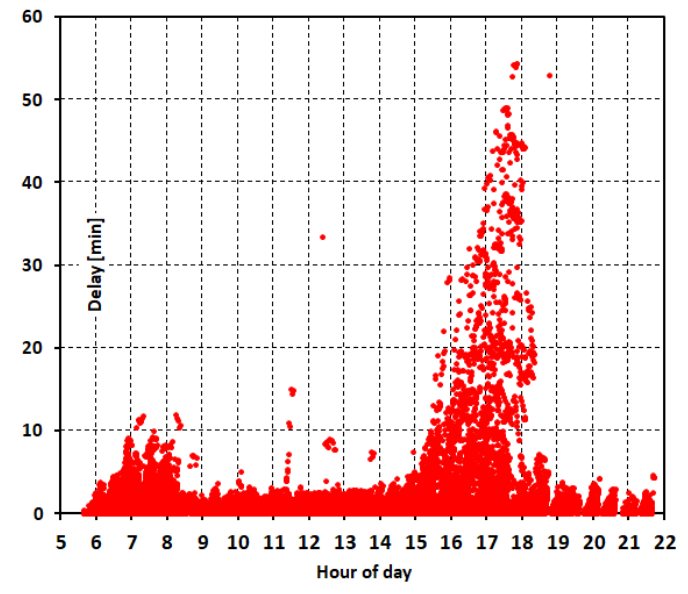

Fig. 4. Examplary delays of arrival to final stop on bus route 


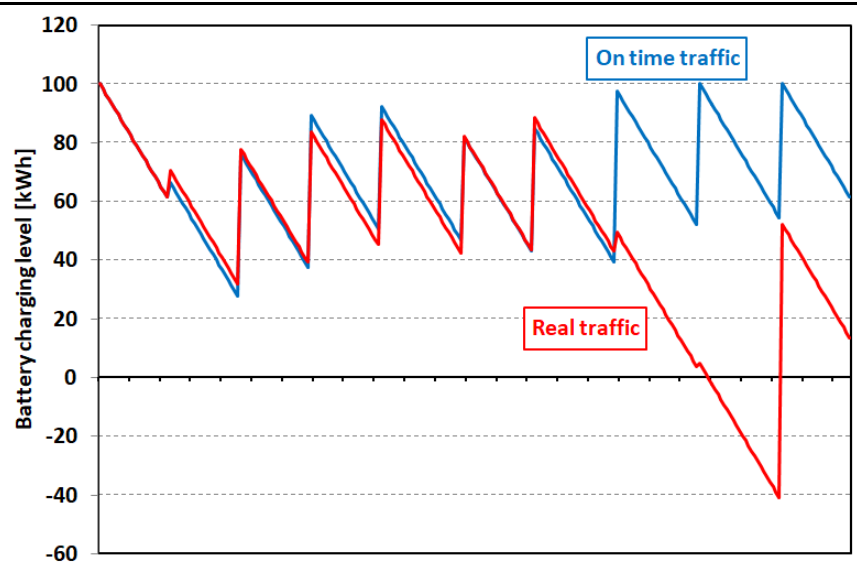

Fig. 5. Influence of traffic delays on battery bus operation - during peak hours delays can cause reduction of stopping time, which can be too short for fully charging

Conclusion. Despite the fact that the number of cities exploiting electric buses in urban transport is increasing, the existing systems are test systems, and there is still no agreement among the users with regard to an optimal and universal solution for electric buses. The issue of charging is one of the biggest problems. On the other hand, trolleybus transport in numerous cities is considered to be outdated. Dynamic charging makes it possible to combine the advantages of trolleybuses and electric buses.

\section{REFERENCES}

1.Bartłomiejczyk, M. 2015 Smart Grid technologies in electric power supply systems of public transport, 12th International Conference: Modern Electrified Transport 2015: .8-14

2.Bartłomiejczyk, M.; Połom, M. 2015. Integracja systemu energetycznego miejskiego transportu szynowego i stacji ładowania autobusów elektrycznych - szansa czy zagrożenie: Technika Transportu Szynowego 7-8: 12-15

3.Bartłomiejczyk, M.; Połom, M. 2015. Uwagi na marginesie artykułu Adama Moleckiego Rozwój autobusów elektrycznych w oparciu o istniejące sieci tramwajowe: Autobusy. Technika, Eksploatacja, Systemy Transportowe 1-2: 46-49

4.Połom, M.; Piasecki, A.; Bartłomiejczyk, M. 2015. Charakterystyka autonomiczności trolejbusów - nowe doświadczenia w elektromobilności miejskiej: Logistyka 4: 5394-5401

5.Bergk, F.; Pütz, R. Potential of In-Motion Charging Buses for the Electrification of Urban Bus Lines, Konferencja", Electromobility in public transport, Gdynia, 9.06.2016

6.Bartłomiejczyk, M.; Połom, M. 2015. Nowoczesna koncepcja rozwoju transportu trolejbusowego : projekt Slide-ln: Autobusy, Technika, Eksploatacja, Systemy Transportowe 7-8:32-35

7.Bartłomiejczyk, M.; Stýskala V.; Hrbac, R.; Połom, M. 2015 Trolleybus with traction batteries for autonomous runnin”, W: 7th International Scientific Symposium on Electrical Power Engineering (ELEKTROENERGETIKA),

8.Bartłomiejczyk, M.; Połom, M. 2011. Alternatywne źródła zasilania w trolejbusach - przegląd rozwiązań stosowanych w miastach europejskich: Technika Transportu Szynowego 3. 9.06.2016

9.Manheller, M. Cost factors in real fleet duty - Vossloh Kiepe, Conference, Electromobility in public transport, Gdynia,

10. Bartłomiejczyk, M.; Połom, M. 2017. The impact of the overhead line's power supply system spatial differentiation on the energy consumption of trolleybus transport: planning and economic aspects: Transport 32(1): 1-12, doi:10.3846/16484142.2015.1101611, ISSN 1648-4142

11. Hebel, K.; Wołek, M., 2016. Perception of modes of public transport compared to travel behaviour of urban inhabitants in light of marketing research, Scientific Journal of Silesian University of Technology. Series Transpor, 92: 65-75. ISSN: 0209-3324. DOI: 10.20858/sjsutst.2016.92.7.

12. Hrbáč, R.; Kolář, V.; Mlčák, T. 2015. Distributed measurement system with GPS synchronisation and its use in electric traction: Elektronika ir elektrotechnika 21 (6): 8-13. ISSN: 1392-1215.

13. Bartłomiejczyk, M. Praktyczna aplikacja In Motion Charging w Gdyni: trolejbusy w obsłudze linii autobusowych. 2016. Autobusy. Technika, Eksploatacja, Systemy Transportowe 9: 18-24

14. http://www.slidein.se/en/about-the-project/

15. Bartłomiejczyk, M.: Dynamic charging of electric buses. De Gruyter Poland, Warsaw (2018).

AUTHOR:

Mikolaj BARTLOMIEJCZYK, Researcher at Gdańsk University of Technology and Energy Specialist in Trolleybus Transport Company in Gdynia. e-mail: mikolaj.bartlomiejczyk@pg.edu.pl 